Yüzüncü Y1l Üniversitesi
Tarim Bilimleri Dergisi

Research article (Araştırma makalesi)

Is The Natural Honey Bee Biodiversity of Anatolia in the Process of Extinction? ${ }^{* *}$

\author{
Merve KAMBUR ACAR ${ }^{* 1}$, Meral KEKEÇOĞLU² \\ ${ }^{1}$ Düzce University, Duzce Vocational School, Beekeeping Program, 81010, Düzce, Turkey \\ ${ }^{2}$ Düzce University, Faculty of Arts and Sciences, Department of Biology, 81620, Konuralp, Düzce, Turkey \\ ${ }^{1}$ https://orcid.org/0000-0001-9658-6584 ' https://orcid.org/0000-0002-2564-8343 \\ *Corresponding author e-mail: mervekambur@gmail.com
}

\section{Article Info}

Received: 02.04.2020

Accepted: 07.08.2020

Online Published: 30.09 .2020

DOI: $10.29133 /$ yyutbd.708186

\section{Keywords}

Apis mellifera L., Biodiversity, Morphometry, Turkey.

\begin{abstract}
This study was conducted through the geometric morphometric method by making a sampling as to represent seven geographical regions of Turkey and also all honeybee races that are reported to be found in Turkey. Nineteen landmarks on the wings of bees detected by using right front wings of worker bees were measured by the Bs200Pro program. According to the results of discriminant function analysis based on individual data, the true classification rate was found to be $54.1 \%$. While the Marmara, Aegean, Eastern Anatolia and Black Sea Regions formed a strictly single group, the Southeastern Anatolia Region distinctly separated from other regions. The honey bee population of eastern and western parts of the Mediterranean Sea were divided into two, while the western part formed close groups with other regions, the eastern part got closer to the Southeastern Anatolia Region. The group center of the Central Anatolia Region partly separated from the other regions and formed a group at the edge. Beside the split of the Mediterranean Region as East and West, the samples taken from Southeastern Anatolian Region create a separate group supported the existence of Apis mellifera syriaca and Apis mellifera meda races in the South. The separation of the Central Anatolia Region supports the existence of Apis mellifera anatoliaca in Central Anatolia of Turkey. However, the examples taken from other regions nested together to create a group show that the honey bee biodiversity in Turkey has been affected by the migratory beekeeping and commercial queenbee activities in recent years.
\end{abstract}

\title{
Anadolu’daki Bal Arısı Biyoçeşitliliği Yok Olma Sürecinde mi?
}

\section{Makale Bilgileri}

Geliş: 02.04.2020

Kabul: 07.08.2020

Online Yayınlanma 30.09.2020

DOI: 10.29133 yyutbd.708186

\section{Anahtar kelimeler}

Apis mellifera L., Biyoçeşitlilik,

Morfometri,

Türkiye.
Öz: Bu araştırmada, Türkiye'nin 7 coğrafik bölgesini ve Türkiye' de bulunduğu bildirilen tüm alt türleri temsil edecek şekilde örnekleme yapılmış ve geometrik morfometri yöntemi ile Türkiye bal arısı biyoçeşitliliğinin son durumu ortaya konmuştur. İşçi arıların sağ ön kanatları kullanılarak kanatlar üzerinde belirlenen on dokuz landmark Bs200Pro programıyla ölçülmüştür. Bireysel veriler esas alınarak yapılan diskriminant fonksiyon analiz sonuçlarına göre gerçek gruplara doğru sınıflandırma oranı \% 54.1'dir. Marmara, Ege, Doğu Anadolu ve Karadeniz Bölgeleri sıkı bir şekilde tek grup oluştururken, Güneydoğu Anadolu Bölgesi diğer bölgelerden belirgin şekilde ayrılmıştır. Akdeniz'in doğusu ve batısı ikiye ayrılmış, batı kısmı diğer bölgelerle iç içe geçerken doğu kısmı Güneydoğu Anadolu Bölgesi’ne yakın ayrı bir grup oluşturmuştur. İç Anadolu Bölgesi'nin grup merkezi diğer bölgelerden ayrilarak kenarda bir grup oluşturmuştur. Güneydoğu Anadolu Bölgesi'nin tek başına, Akdeniz Bölgesi'nin doğu ile batısının ayrı bir grup oluşturması Türkiye'nin güneyinde Apis mellifera syriaca ve Apis mellifera meda ırklarının varlığını 
destekler niteliktedir. İç Anadolu Bölgesi'nin ayrılması ise Orta Anadolu’da ise Apis mellifera anatoliaca olduğunu destekler niteliktedir. Ancak diğer bölgelerden alınan örneklerin iç içe geçerek birlikte bir grup oluşturması Türkiye bal arısı biyoçeşitliliğinin son yıllardaki göçer arıcılık ve ticari ana arı faaliyetlerinden etkilendiğini göstermektedir.

\footnotetext{
* This study is part of the master thesis and it was supported by the Scientific Research Project of Duzce University BAP-2015.05.01.318.
}

\section{Introduction}

The honey bee (Apis mellifera L.), which was wondered about from past to present because of its ecological, economic and social organization and encouraged many scientists to carry out research, divide into in 4 evolutionary branches; branch A; African subspecies, M branch; Western Europe and North Africa subspecies, branch C; Central and Eastern European subspecies, branch O; Northeast Mediterranean and Middle East subspecies (Ruttner 1988; Arias and Sheppaard 1996; Franck et al 2000). In addition, the $Y$ branch was proposed as the fifth evolutionary branch for the Northeast African subspecies (Franck et al., 2001).

There are three theories about the evolution of honey bees. The first of these suggested by Rothenbuhler and Kerr (1968) is that the honey bees had bred in Southeast Asia and India. The second theory asserts that honey bees bred in Africa and spread to Europe through the Middle East (Wilson, 1971). According to Ruttner's (1988) theory, honeybees emerged in the south of the Caspian Sea near Anatolia and spread to Europe and Africa along the Arabian Peninsula using Anatolia as a migration route. Due to its geographical location, Anatolia function as a bridge between Europe and Asia. The only way the honey bee originating from the south of the Caspian Sea or from Africa can pass to Europe is Anatolia. Therefore, Anatolia is the gene centre for many honeybee breeds. In addition, thanks to its rich flora, climate pattern varying from region to region, and because of different flora regions (Iran-Turanian, Mediterranean, Euro-Siberian flora regions) it is also highly advantageous in terms of beekeeping activities.

Five of the identified twenty nine subspecies reported to be located within the borders of Turkey (Sheppard and Meixner, 2003). According to morphometric definitions, whereas Apis mellifera anatoliaca, has a wide spreading area in the inner parts of Anatolia, Apis mellifera caucasica in the Northeast of the Black Sea, Apis mellifera meda that is seen in Eastern Anatolia near the Iranian border are grouped in the branch O (Ruttner, 1988; Franck et al., 2000; Pritchard et al., 2000; Franck et al., 2001; Arias and Sheppard, 2003; Sheppard and Meixner, 2003). According to the mitochondrial DNA (mtDNA) analyses, these subspecies were grouped in the C branch (Smith et al., 1997; Franck et al., 2000; Palmer et al., 2000; Ozdil et al., 2009). In addition, Apis mellifera carnica which is a member of C branch was seen in Thracian (Palmer et al., 2000), Apis mellifera syriaca which is a member of the branch $\mathrm{O}$ is seen near the Syrian border of Hatay (Kandemir et al., 2006a). In line with these studies, it is reported that Turkey hosts both the member of branch $\mathrm{C}$ and $\mathrm{O}$.

However, the results of the researches conducted in recent years report that bee biodiversity in Turkey has been largely influenced due to migratory beekeeping and commercial queen sales and the biodiversity has disappeared (Kambur and Kekeçoğlu, 2018a; 2018b). Migratory beekeeping which is made in order to produce more honey following the flowering period is quite common in Turkey. With the early spring period, beekeepers created a seasonal migration route by moving their bees from the coast to the inner parts and from the west to the east (Güler, 2010; Kekeçoğlu et al., 2020). The queen bees that fly to the mating flight with the awakening of nature do not mate with the male bees of the breeds in their region, but mate with the male bees of the regions they move to. This may adversely affect the protection of local breeds, as well as increasing the risk of extinction of existing pure breeds or causing the formation of hybrid forms.

In this study, sampling was done in a way that will represent seven geographical regions of Turkey and all honeybee races that were recorded to live in Turkey. The aim of this study is to determine the current status of honey bee biodiversity and compare it with the literature reports. 


\section{Materials and Methods}

\subsection{Preparation and measurements of samples}

Sampling is made from 32 different locations (Marmara Region; Kırklareli, Çanakkale, Balıkesir, Bursa, Bilecik; Aegean Region: İzmir, Muğla; Mediterranean Region: Antalya, Hatay, Kahramanmaraş; Central Anatolia Region; Kırıkkale, Konya, Niğde, Eskişehir; Black Sea Region: Sakarya, Düzce, Zonguldak, Kastamonu, Amasya, Ordu, Trabzon, Artvin; Eastern Anatolia Region: Ardahan, Kars, Iğdır, Bingöl; Southeast Anatolia Region: Gazinatep), which will represent the seven geographical regions of Turkey, selected 15 worker bees from each 3 colonies of 3 different apiaries in each location out of totally 288 colonies. Samples were transported to the laboratory with $20 \mathrm{ml}$ scintillation vials containing $96 \%$ of ethyl alcohol. Right front wings of worker bees were used.

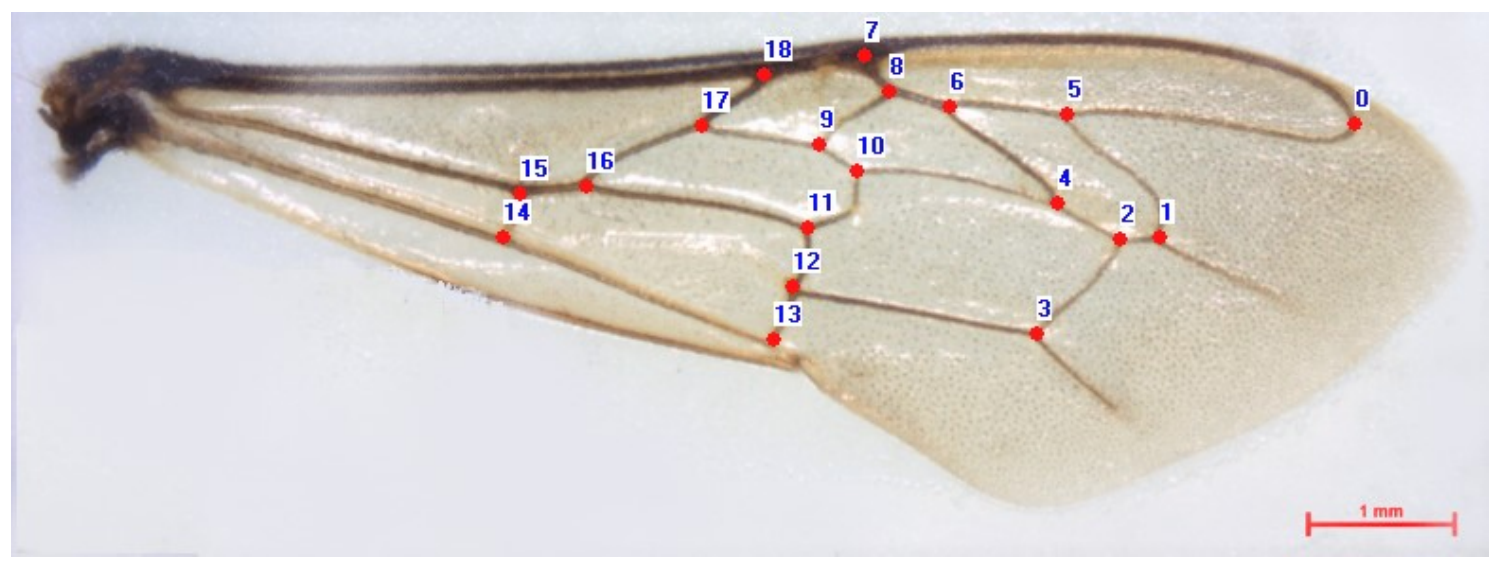

Figure1. Automatic landmark marking made with BAB Bs200 Program.

Wing prepares were prepared according to Kekeçoğlu, (2007) and photographs were taken at $1 \mathrm{X}$ magnification with BAB camera system connected to BAB STR45 stereo zoom microscope. Automatic measurement of the $\mathrm{X}$ and $\mathrm{Y}$ coordinates of 19 landmarks determined on the wings was performed with Bs200Pro program (Kambur, 2017).

\subsection{Statistical Analysis}

Morphometric data were evaluated using discriminant function analysis (DFA) in SPSS 15.0 package program. Univarate (ANOVA) and multivariate (MANOVA) variance analyses were used to determine intra- and inter-group variation. Cross-validation test (CVT) was used to see the distribution of the populations to real groups (SPSS, 2005). To see the relationship between the populations, using Mahalanobis distance and PHYLIP 3.67 (Rohlf, 2000) program, UPGMA (Unweighted pair group method with arithmetic mean) Cluster Analysis was carried out.

\section{Results}

Discriminant function analysis was utilized to determine the distribution of individuals in groups in multidimensional environment. The discriminant functions that help the populations to be classified were determined according to the cartesian coordinate values of nineteen landmarks. The number of functions included in the analysis, their significance levels, eigenvalues, percentages of variation (\%), cumulative values (\%), canonical correlation values, Wilk's lambda, chi-square values and degrees of freedom are given in Table 1. 
Table 1. Number of functions of populations and values expressing these functions

\begin{tabular}{llllllllc}
\hline $\begin{array}{l}\text { Number of } \\
\text { Functions }\end{array}$ & Eigenvalues & $\begin{array}{l}\text { Variance } \\
\text { Value (\%) }\end{array}$ & $\begin{array}{l}\text { Cumulative } \\
\text { Value (\%) }\end{array}$ & $\begin{array}{l}\text { Canonical } \\
\text { Correlation }\end{array}$ & $\begin{array}{l}\text { Wilks' } \\
\text { Lambda }\end{array}$ & $\begin{array}{l}\text { Chi- } \\
\text { square }\end{array}$ & Df & $\begin{array}{l}\text { Significance } \\
\text { Level (p) }\end{array}$ \\
\hline 1 & 1.144 & 53 & 53 & 0.731 & 0.19 & 6882.18 & 192 & $0^{*}$ \\
2 & .480 & 22.2 & 75.2 & 0.569 & 0.41 & 3704.57 & 155 & $0^{*}$ \\
3 & .208 & 9.6 & 84.8 & 0.415 & 0.60 & 2071.72 & 120 & $0^{*}$ \\
4 & .183 & 8.5 & 93.3 & 0.393 & 0.73 & 1283.61 & 87 & $0^{*}$ \\
5 & .091 & 4.2 & 97.5 & 0.288 & 0.86 & 584.48 & 56 & $0^{*}$ \\
6 & .055 & 2.5 & 100 & 0.228 & 0.94 & 222.58 & 27 & $0^{*}$ \\
\hline
\end{tabular}

As a result of the analysis of variance applied to the sample data, the significance level of all $\mathrm{x}, \mathrm{y}$ coordinates effective on discriminant functions was supported by ANOVA and the variation between the groups was found to be significant $(\mathrm{P}<0.05)$.

When the $\mathrm{X}$ and $\mathrm{Y}$ coordinate data were compared with MANOVA based on the data of the groups representing the populations, significant differences were found between populations of all regions in terms of at least one coordinate $(\mathrm{P}<0.05)$.

In discriminant function analysis, group centre of populations were separated with a stricter grouping (Figure 2). When Figure 2 is examined, it is seen that the group center of Southeast Anatolia Region is separated from other regions. The Mediterranean Region is divided into two parts. Although one part is close to the Southeastern Anatolia region, the other part is distributed among Black Sea, Marmara, Aegean and Eastern Anatolia Regions. Group centers of Black Sea and Eastern Anatolia, Aegean and Marmara regions overlap and these regions are intertwined.

Canonical Discriminant Functions

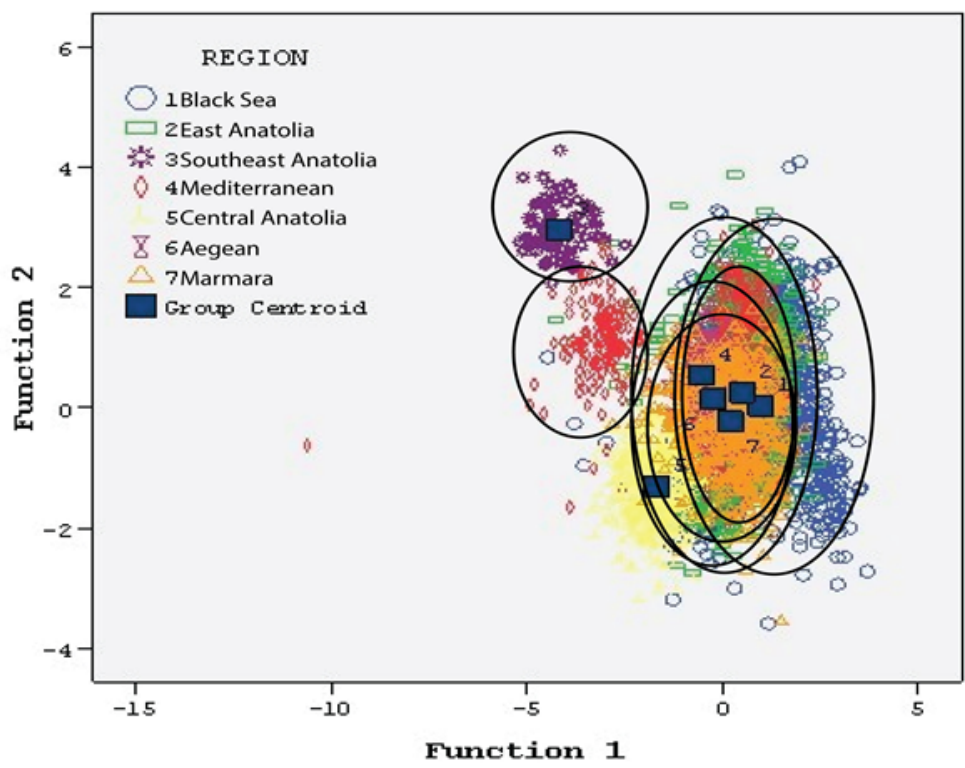

Figure 2. Clustering of populations by discriminant function analysis -DFA (1:Black Sea, 2:East Anatolia, 3:Southeast Anatolia, 4:Mediterranean, 5:Central Anatolian, 6: Aegean, 7:Marmara).

According to the results of discriminant function analysis performed based on raw data, the true classification rate was found to be $54.1 \%$. Table 2 shows the estimated group memberships in terms of morphological characteristics worker honeybee wings according to the obtained distinction functions. According to the estimated group memberships, it was determined that $48.2 \%$ in the Black Sea Region, 54.5\% in Eastern Anatolia Region, 100\% in Southeast Anatolia Region, 30.8\% in Mediterranean Region, 94.2\% in Central Anatolia Region, 55.6\% in Aegean Region and 48.8\% in Marmara Region remained in their own group. It was detected that the highest crossing from the Black 
Sea was to Eastern Anatolia (18.6\%), the highest crossing from Eastern Anatolia was to the Black Sea (15.1\%), the highest crossing from the Mediterranean was to the Black Sea (14.6\%), the highest crossing from Central Anatolia was to the Mediterranean (3\%), the highest crossing from the Aegean was to Marmara (17.5\%) and the highest crossing from Marmara was to the Aegean (16.9) (Table 2).

Table 2. Grouping of samples by cross-validation test (CVT)

\begin{tabular}{|c|c|c|c|c|c|c|c|c|}
\hline \multicolumn{9}{|c|}{ Predicted Group Membership } \\
\hline Region & Black Sea & East Anatolia & $\begin{array}{c}\text { Southeastern } \\
\text { Anatolia }\end{array}$ & Mediterranean & $\begin{array}{c}\text { Central } \\
\text { Anatolia }\end{array}$ & Aegean & $\begin{array}{c}\text { Marmar } \\
\text { a }\end{array}$ & Total \\
\hline Black Sea & $611(\% 48.2)$ & $236(\% 18.6)$ & $1(0.1)$ & $88(\% 6.9)$ & $\begin{array}{l}112 \\
(\% 8.8)\end{array}$ & $70(\% 5.5)$ & $\begin{array}{l}149 \\
(\% 11.8)\end{array}$ & $\begin{array}{l}1267 \\
(\% 100)\end{array}$ \\
\hline East Anatolia & $98(\% 15.1)$ & $353(\% 54.5)$ & $5(\% 0.8)$ & $34(\% 5.2)$ & $\begin{array}{l}56 \\
(\% 8.6)\end{array}$ & $39(\% 6)$ & $\begin{array}{l}63 \\
(\% 9.7)\end{array}$ & $\begin{array}{l}648 \\
(\% 100)\end{array}$ \\
\hline $\begin{array}{l}\text { Southeastern } \\
\text { Anatolia }\end{array}$ & 0 & 0 & $86(\% 100)$ & 0 & 0 & 0 & 0 & $\begin{array}{l}86 \\
(\% 100)\end{array}$ \\
\hline Mediterranean & $94(\% 14.6)$ & $80(\% 12.5)$ & $74(\% 11.5)$ & $198(\% 30.8)$ & $32(\% 5)$ & $89(\% 13.9)$ & $\begin{array}{l}75 \\
(\% 11.7)\end{array}$ & $\begin{array}{l}642 \\
(\% 100)\end{array}$ \\
\hline $\begin{array}{l}\text { Central } \\
\text { Anatolia }\end{array}$ & 0 & 0 & 0 & $16(\% 3)$ & $\begin{array}{l}501 \\
(\% 94.2)\end{array}$ & $5(\% 0.9)$ & $\begin{array}{l}10 \\
(\% 1.9)\end{array}$ & $\begin{array}{l}532 \\
(\% 100)\end{array}$ \\
\hline Aegean & $10(\% 4)$ & $24(\% 9.5)$ & 0 & $34(\% 13.5)$ & 0 & $140(\% 55.6)$ & $\begin{array}{l}44 \\
(\% 17.5)\end{array}$ & $\begin{array}{l}252 \\
(\% 100)\end{array}$ \\
\hline Marmara & $74(\% 11.3)$ & $80(\% 12.3)$ & 0 & $47(\% 7.2)$ & $\begin{array}{l}23 \\
(\% 3.5)\end{array}$ & $110(\% 16.9)$ & $\begin{array}{l}318 \\
(\% 48.8)\end{array}$ & $\begin{array}{l}652 \\
(\% 100)\end{array}$ \\
\hline
\end{tabular}

In the dendogram drawn according to the Mahalonobis distances while the Southeastern Anatolia Region and the Central Anatolia Region form a group together, the Eastern Anatolia, Black Sea, Mediterranean, Aegean and Marmara Regions together formed a separate group (Figure 3).
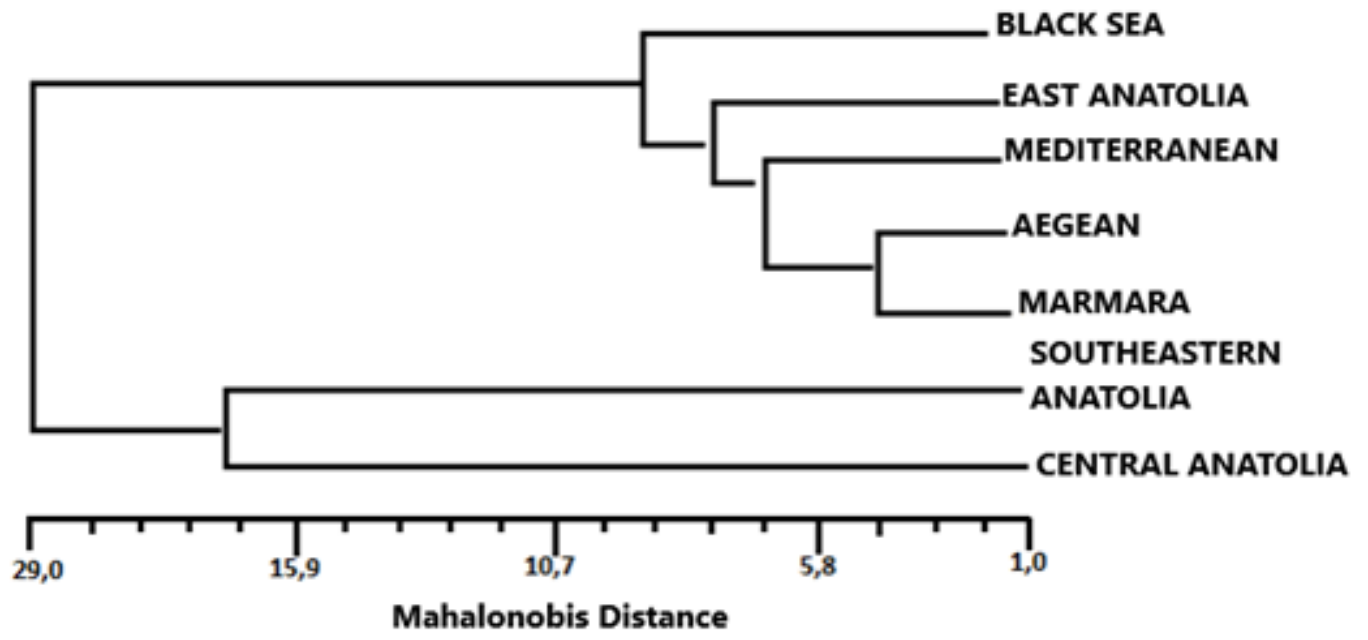

Figure 3. UPGMA phenogram of populations.

\section{Discussion and Conclusion}

In this study, Turkey's honey bee populations were evaluated according to 7 geographical regions by using morphometric method. While the Marmara, Aegean, Eastern Anatolia and Black Sea Regions formed a group, the Southeastern Anatolia Region was distinctly separated from other regions. The eastern and western parts of the Mediterranean were divided into two, and the western part formed a group with the other five regional honey bee populations, the eastern part got closer to the Southeastern Anatolian Region. The group center of the honey bee population in Central Anatolia was partially separated from the other regions and formed a seperate group on the edge. According to 
previous researches, Apis mellifera subspecies in Anatolia were reported that Apis mellifera caucasica was widespread in the region from Samsun to the northeast of the country, Apis mellifera syriaca in a small area on the border with Syria in the South, Apis mellifera meda in Southeast Anatolia and Apis mellifera anatoliaca in all other regions (Ruttner, 1988; Kandemir et al., 2000; Güler and Bek, 2002; Kandemir et al., 2005).

In this study, it can be stated that Apis mellifera meda race still exists in Southeastern Anatolia Region, which constitutes a separate group. Furthermore, the division of the eastern and western parts of the Mediterranean Region supports the findings of the presence of Apis mellifera syriaca in Hatay which is located in the eastern part of the Mediterranean (Özbakır, 2011) The Anatolian Diagonal of the Amanos Mountains separating the east and the west of the Mediterranean Region may also have an effect on this differentiation of geographical barriers.

Five different honey bee races have been identified in Turkey related to the evolutionary history of honey bees. These races are grouped in the $\mathrm{O}$ evolutionary lineage according to morphometric studies (Ruttner 1988; Franck et al., 2000; Pritchard et al., 2000; Franck et al., 2001; Arias and Sheppard, 2003; Sheppard and Meixner, 2003), whereas mtDNA studies have shown that these subspecies belong to the C evolutionary lineage (Smith et al., 1997; Franck et al., 2000; Palmer et al., 2000; Özdil et al., 2009). The nucleotide sequence of COI-COII gene region with the Apis mellifera syriaca has a different nucleotide sequence compared to the other mtDNA haplotype groups (Eastern Europe, Western Europe and Africa). Apis mellifera syriaca has therefore been reported to represent a 4th mtDNA haplotype group (O) (Franck et al., 2000; Özdil et al., 2009; Kandemir et al., 2006b). Two main groups were formed according to DFA results and UPGMA graph of this study. Therefore, this result is consistent with the literature stating that honeybee races in Turkey are members of the $\mathrm{O}$ and $\mathrm{C}$ evolutionary lineage.

In previous studies, it has been reported that the northeast and southeast part of Turkey exactly separated from each other. It was found that Apis mellifera meda exist in the southeast part of Turkey (Ruttner, 1988; Kandemir et al., 2000; Güler and Bek, 2002; Kekeçoğlu et al., 2009; Kekeçoğlu and Soysal, 2010; Bouga et al., 2011; Özbakır, 2011; Koca and Kandemir, 2013; Kambur and Kekeçoğlu, 2018a; 2018b). Apis mellifera syriaca was in Hatay near the Syrian border of Turkey (Kandemir et al 2006a). Özbakır (2011) compared the samples collected from Syria and Iran and Turkey's provinces (Hatay, Urfa and Mardin) in southern Turkey and reported that the samples collected from these provinces overlap with the Syrian samples (Apis mellifera syriaca). Research results based on molecular techniques indicate the presence of both Apis mellifera syriaca and Apis mellifera meda subspecies in southeastern part of Turkey (Kandemir et al., 2000; Palmer et al., 2000; Pritchard et al., 2000; Kandemir et al., 2006a). In this study, the fact that the samples taken from the eastern part of the Mediterranean Region separated from the west, and that the samples taken from the Southeastern Anatolia Region formed a separate group alone support the existence of two different subspecies in the Southern part of Turkey.

Ruttner, (1988) stated that Apis mellifera caucasica existed in northeast Turkey. On the other hand, according to subsequent studies, samples taken from the Eastern Black Sea Region, where Apis mellifera caucasica is common, were not separated from samples taken from the western Mediterranean, Marmara Aegean and the rest of the Black Sea Region and formed a group together. When all regions were evaluated together in the cross-validation test, the distribution of samples to their groups was $54.1 \%$. The distribution of the samples taken from the Black Sea, Eastern Anatolia, Marmara and Aegean Regions to their real groups is $48.2 \%, 54.5 \%, 48.8 \%$ and $55.6 \%$, respectively.

Seasonal migratory beekeeping activities in Turkey, can made as regional and also troughout Turkey within long distances, except for some isolated area with regard to genetic conservation (Siral1, 2002). For this reason, some honey bees such as subspecies, local ecotypes, under the effects of hybridization and loss of genetic structure (De la Rùa, 2009; Güler, 2010). Some efforts were performed to eliminate this undesirable effects. A few of this, efforts are comprise restricted migratory beekeping areas within the geographic regions legally and promote beekeepers make their activities in this areas. However, there are still shortcomings in terms of implementation and functionality of legal measures. Queen bee trade and transportations should be allow confined fields, thus genetic make up can be protected or loss of levels keep at minimum rates natural Turkish honey bee populations.

In this study, the fact that group membership in regions other than Central Anatolia and Southeastern Anatolia was so low was thought to be the result of migratory beekeeping practice or 
commercial queen bee trade, which is common in Turkey. This may be the result of the Caucasian queen bee production from one source and its distribution throughout the country (Güler, 2010; Kekeçoğlu, 2018).

Honey bees serve a function in pollination of plants intended for consumption, due to this reason, we have to keep the best management and field practise, It was indicated in this study that honey bee diversity of Turkey encounter hybridization threat caused by migratory beekeping activities. In this case, morphological and morfometric distinctions of Anatolian honey bees may be remain incapable (Kence, 2006; Güler, 2010; Kekeçoğlu \& Soysal, 2010). Hence, our study contribute to insight for necessity of sustainable protection programs.

In conclusion, in this study based on geometric morphometric method, it was determined that there could be two different lineages in southern Turkey. However, the effect of migratory beekeeping is observed in the remaining parts of Turkey. With extensive studies using morphometric and molecular methods together, it is suggested that the existing races and ecotypes should be identified urgently and protection areas should be established.

\section{Acknowledgment}

This study is part of the master thesis and it was supported by the Scientific Research Project of Duzce University BAP-2015.05.01.318.

\section{References}

Arias, M. C., \& Sheppard, W. S. (1996). Molecular phylogenetics of honey bee subspecies (Apis mellifera L) inferred from mitochondrial DNA Seqquence. Molecular Phelogenetics Evolution, 5(3), 557-566.

Bouga, M., Alaux, C., Bienkowska, M., Büchler, R., Carreck, N. L., Cauia, E., Dahle, B., Dall’Olio, R., De la Rua, P., Gregorc, A., Ivanova, E., Kence, A., Kence, M., Kezic, N., Kiprijanovska, H., Kozmus, P., Kryger, P., Le Conte, Y., Lodesani, M., Murilhas, A. M., Scieanu, A., Soland, G., Uzunov. A., \& Wilde, J. (2011). A review of methods for discrimination of honey bee populations as applied to European beekeeping, Journal of Apicultural Research, 50(1),51-84.

De la Rùa, P., Jaffe, R., Dall' Olio, R., Munoz, I., \& Serrano, J. (2009). Biodiversity, conservation and current threat to European honey bees. Apidologie, 40, 263-284.

Franck, P., Garnery, L., Celebrano, G., Solignac, M., \& Cornuet, J.M. (2000). Hybrid origins of honeybees from Italy (A. m. ligustica) and Sicily (A. m. sicula). Molecular Ecology, 9(7), 907921.

Franck, P., Garnery, L., Loiseau, A., Oldroyd, B. P., Hepburn, H. R., Solignac, M., \& Cornuet, J. M. (2001). Genetic diversity of the honeybee in Africa: microsatellite and mitochondrial data. Heredity, 86, 420-430.

Güler, A. (2001). Artvin Borçka Camili ( Macahel ) Yöresi Bal Arısı (Apis mellifera L .)' nın Morfolojik Özellikleri. The Turkish Journal of Veterinary and Animal Sciences, 25, 473-481.

Guler, A., \& Bek, Y. (2002). Forewing angles of honey bee (Apis mellifera) samples from different regions of Turkey. Journal of Apicultural Research, 41(1-2), 43-49.

Guler, A. (2010). A morphometric model for determining the effect of commercial queen bee usage on the native honeybee (Apis mellifera L.) population in a Turkish province. Apidologie, 41(6), 622-635.

Kambur, M. (2017). Determination of Honey Bee (Apis Mellifera L.) Biodiversity of Turkey by Using Geometric Morphometric Methods, (MSc Thesis), Düzce University, Institute of Science, Düzce, Turkey.

Kambur, M., \& Kekeçoğlu, M. (2018a). The loss of genetic diversity on native Turkish honey bee (Apis mellifera L.) subspecies. Anadolu Journal of Agriculture Science, 33, 73-84.

Kambur, M, \& Kekecoglu, M. (2018b). The current situation of Turkey Honey Bee (Apis mellifera L.) biodiversity and conservations studies. Biodicon, 11(1), 105-119.

Kandemir, I., Kence, M., \& Kence, A. (2000). Genetic and morphometric variation in honeybee (Apis mellifera L.) populations of Turkey. Apidologie, 31(1), 343-356. 
Kandemir, I., Kence, M., \& Kence, A. (2005). Morphometric and electrophoretic variation in different honeybee (Apis mellifera L.) populations. The Turkish Journal of Veterinary and Animal Sciences, 29(3), 885-890.

Kandemir, I., Pinto, M. A, Meixner, M.D., \& Sheppard, W.S. (2006a). Hinf-I digestion of cytochrome oxidase I region is not a diagnostic test for A. m. lamarckii. Genetics and Molecular Biology, 29(4), 747-749.

Kandemir, I., Kence, M., Sheppard, W.S., \& Kence, A. (2006b). Mitochondrial DNA variation in honey bee (Apis mellifera L.) populations from Turkey. Journal of Apicultural Research Bee World, 45(1), 33-38.

Kekecoglu M (2007). A comparative investigation of honeybee ecotypes of turkey by means of mtdna and some morphological traits, Ph.D. Thesis, Namık Kemal University, Institute of Science, Tekirdağ, Turkey.

Kekeçoğlu, M., Bouga, M., Soysal, M. I., \& Harizanis, P. (2009). Genetıc Divergence and Phylogenetic Relationships of Honey Bee Populations From Turkey Using Pcr-Rflp's Analysis of Two mtDNA Segments. Bulgarian Journal of Agricultural Sci., 15 (6), 589-597.

Kekeçoğlu, M., \& Soysal M. I. (2010). Genetıc Diversity of Bee Ecotypes in Turkey and Evidence for Geographical Differences. Romanian Biotechnological Letters, 15 (5), 5646-5653.

Kekeçoğlu, M., Eroğlu, N., Kambur, M., \& Uçak, M. (2020). The relationships between propolis collecting capability and morphometric features of some honey bee races and ecotypes in anatolia. Journal of Agricultural Sciences, 26 (1).

Kence, A. (2006). Türkiye balarılarında genetik çeşlitlilik ve korunmasının önemi. Uludağ Arıclık Dergisi, 6, 25-32.

Koca, A.Ö., \& Kandemir, İ. (2013). Comparison of two morphometric methods for discriminating honey bee (Apis mellifera L.) populations in Turkey. Turkish Journal of Zoology 37, 205-210.

Özbakır, G. Ö. (2011). Türkiye’nin güneydoğu sinırboyu bal arısı populasyonlarının (Apis mellifera L.) morfolojik özellikleri, Ph.D. Thesis, Ankara University, Ankara, Turkey.

Ozdil, F., Yıldız, M. A., \& Hall, H. G. (2009). Molecular characterization of Turkish honey bee populations (Apis mellifera) inferred from mitochondrial DNA RFLP and sequence results. Apidologie 40, 570-576.

Palmer, M.R., Smith, D.R., \& Kaftanoğlu, O. (2000). Turkish honeybees: Genetic variation and evidence for a fourth lineage of Apis mellifera mtDNA. Journal of Heredity 91(1), 42-46.

Pritchard, J.K., Stephens, M., \& Donnelly, P. (2000). Inference of Population Structure Using Multilocus Genotype Data. Genetics, 156,945-959.

Rohlf, F.J. (2000). NTSYS-pc numerical taxonomy and multivariate analysis system, version 2.20e, Exeter Publication, New York.

Rothenbuhler, W.C, \& Kerr, W.E. (1968). Bee genetics. Annual Review of Genetics 2, 413-438.

Ruttner, F. (1988). Biogeography and taxonomy of honeybees. Springer-Verlag Berlin Heidelberg $\mathrm{GmbH}$.

Sheppard, W.S., \& Meixner, M.D. (2003). Apis mellifera pomonella, a new honey bee subspecies from Central Asia. Apidologie, 34, 367-375.

Siralı, R. (2002). General beekeeping structure of Turkey. Journal of Uludağ Beekeeping Research, 4, 31-40.

Smith, D.R., Slaymaker, A., Palmer, M., \& Kaftanoğlu, O. (1997). Turkish mitochondrial lineage. Apidologie 28(1), 269-274.

SPSS. (2005). IBM SPSS Statistics 15.0 for Windows. Armonk, NY.

Wilson, E. O. (1971). The Insect Societies. Harvard University Press. Cambridge, Mass. 